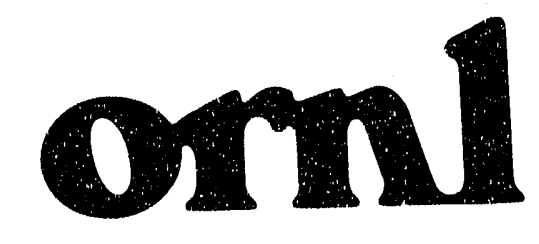

OAK RIDGE NATIONAL LABORATORY

MARTIN MALUETMA
Rewingl begen

DEC 261991

ORNL/TM-11878
Iridium-Alloy Processing

Experience in FY 1990

E. K. Ohriner

MANAGED BY

MARTIN MARIETTA ENERGY SYSTEMS, INC.

FOR THE UNITED STATES

DEPARTMENT OF ENERGY

DSTRIBUTION OF THIS DOCUMEAT IS INLIMITEO: 
This report has been reproduced directly from the best avallable copy.

Available to DOE and DOE contractors from the Office of Scientific and Technical Information, P.O. Box 62, Oak Ridge, TN 37831; prices avallable from (615) 576-8401, FTS 626-8401.

Avallable to the public from the National Technical Information Service, U.S. Department of Commerce, 5285 Port Royal Rd., Springfield, VA 22161.

This report was prepared as an account of work sponsored by an agency of the United States Government. Neither the United States Government nor any agency thereof, nor any of their employees, makes any warranty, express or implied, or assumes any legal llebility or responsibility for the accuracy, completeness, or usefuiness of any information, apparatus, product, or process disclosed, or represents that its use would not infringe privately owned rights. Reference herein to any specific commercial product, process, or service by trade name, trademark, manufacturer, or otherwise, does not necessarily constitute or imply its endorsement, recommendation, or favoring by the United States Government or any agency thereof. The views and opinions of authors expressed herein do not necessarily state or reflect those of the United States Government or any agency thereof. 
ORNL/TM- -11878

DE92 010519

Metals and Ceramics Division

IRIDIUM-ALLOY PROCESSING EXPERIENCE IN FY 1990

E. K. Ohriner

Date Published: November 1991

\author{
Prepared for \\ DOE Office of Space and Defense Power Systems \\ Office of Special Applications \\ AF 70 10200
}

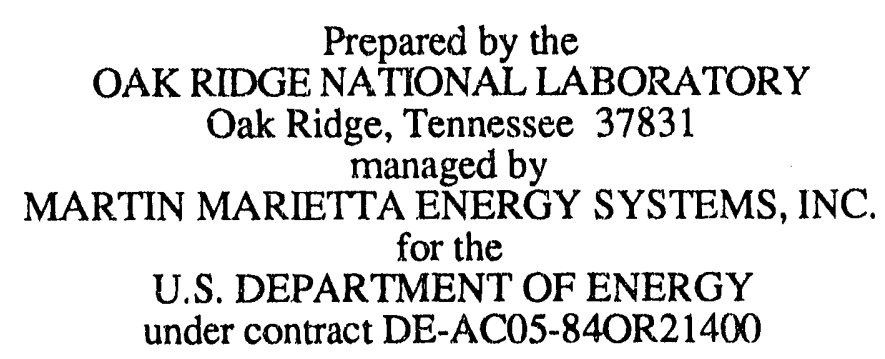

MASTER

DESTRIBUTION OF THIS DUCUMEAT IS UNLIMITED 
CONTENTS

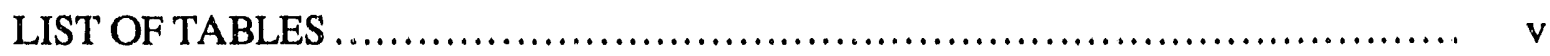

LIST OF FIGURES …............................................................. vii

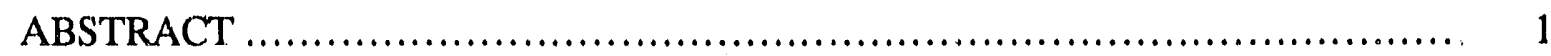

1. INTRODUCTION ..............................................................

2. ELECTRODE FABRICATION ................................................. 2

3. CONSUMABLE-ELECTRODE MELTING ..................................... 3

4. INGOT EXTRUSION …......................................................... 5

5. SHEET ROLLING …......................................................... 8

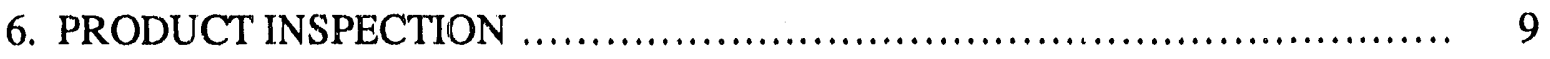

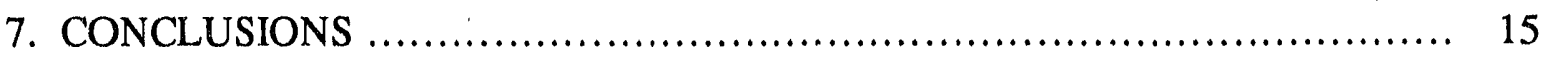

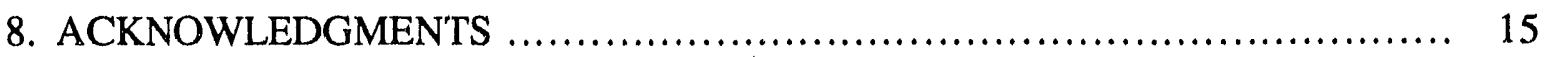

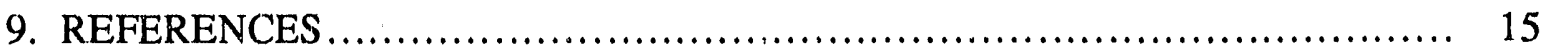




\section{LIST OF TABLES}

Table 1. Current extrusion parameters for iridium alloys......................... 6

Table 2. Summary of ingot size and powder-batch source for consumable-electrode, arc-melted ingots.

Table 3. Summary of Vickers microhardness of iridiumalloy sheet.............................................................

Table 4. Summary of thorium analyses of iridium-alloy sheet 


\section{LIST OF FIGURES}

Fig. 1 Plot of arc-melting parameters for the E? ingot shows maintenance of nominal potential of $30 ;$ and nominal current of $3000 \mathrm{~A}$ after the initial $60-\mathrm{s}$. nelting ...

Fig. 2 Arc-melting parameters for the D2 ingot are similar to those seen in Fig. 1 for the E2 ingot...

Fig. 3 Arc-melting parameters for the E3 ingot are similar to those seen in Fig. 1 for the E2 ingot.

Fig. 4. Plots show that the CR4 extrusion exhibited significantly lower loads early in the extrusion than the D2, E2, and E3 extrusions but also a relatively high load similar to E2 that approached the press capacity of $8.2 \mathrm{MN}$.

Fig. 5. Yields of blanks through ultrasonic examination have increased due to improved processing in FY 1990 and are above the task goal of $85 \%$

Fig. 6. Optical micrograph of as-polished specimen sheet MR424 produced from a $0.75-\mathrm{mm}$-square drop casting shows only a few small intermetallic particles

Fig. 7. Optical micrograph of as-polished sheet specimen B2-3 produced from a 51-mm-diam ingot shows more and larger intermetallic particles than seen in sheet produced from drop castings

Fig. 8. Optical micrograph of as-polished sheet D2-12 specimen produced from a 63-mm-diam ingot shows intermetallic particles, some of which have been elongated in the rolling direction 


\title{
IRIDIUM-ALLOY PROCESSING EXPERIENCE IN FY 1990*
}

\author{
E. K. Ohriner
}

\begin{abstract}
Iridium-alloy blanks and foil are produced at the Oak Ridge National Laboratory for use as fuel cladding material in radioisotope thermoelectric generators for space power sources. Until 1984, the material was produced from small, 500-g drop castings. A new process has been developed in which consumable electrodes of about $10 \mathrm{~kg}$ are arc melted, extruded, and then rolled to produce the sheet products. The work performed during FY 1990 included the consumable-electrode arc melting of four ingots and the extruding and rolling to sheet of four billets. Significant improvements made in the extruding and arc-melting processes during FY 1989 have been demonstrated to dramatically increase the rate of blank acceptance in nondestructive evaluations. Efforts to improve the rolling practice and to better characterize intermetallic particle distributions in the sheet are also described.
\end{abstract}

\section{(1) \\ 1. INTKODUCTION}

The DOP-26 iridium alloy (Ir-0.3\% W- $0.006 \%$ Th- $-0.005 \% \mathrm{Al}$ ) was developed by the Oak Ridge National Laboratory (ORNL) for use as fuel cladding in radioisotope thermoelectric generators (RTGs) used for space power. ${ }^{1}$ Iridium alloy sheet products have been produced at ORNL, for about 20 years. The products are currently produced in the form of DOP-26 alloy blanks and DOP-4 alloy (lr-0.3\% W-0.003\% Th-0.005\% Al) foil. Flight-quality products were produced from small, 500-g, drop-cast ingots and were used in the manufacture of flight hardware for both the Multi-Hundred Watt and General Purpose Heat Source RTGs. In 1984, development of a new iridium-alloy sheet and foil manufacturing process, the consumable-electrode are melting and extrusion of large, $10-\mathrm{kg}$ ingots, was begun. ${ }^{2}$ Since that time, a total of 11 ingots (both experimental and production) has been processed to blanks.

*Research sponsored by Office of Space and Defense Power Systems, Office of Special Applications, U.S. Department of Energy, under contract DE-AC05-84OR214(X) with Martin Mariettå Energy Systems, Inc. 
This report summarizes the production experience for DOP-26 alloy blanks and DOP-4 alloy foil during FY 1990. The results of experimental rolling trials with sheets of iridium scrap are also included. The most important accomplishments have been the production of blanks and foil and the demonstration of a dramatic decrease in the rate of rejection of blanks for ultrasonic indications, using the improvements in arc-melting and extrusion practices made during FY 1989 (ref. 3). The experience with each of the processing steps of electrode fabrication, consumable-electrode melting, ingot conditioning, extrusion, rolling, and inspection are discussed below.

The processing of all materials described in this report was performed under full configuration control. Approved procedural revisions were obtained whenever necessary for all processing of these materials. The sole exception was the RS5 material that consisted of solid scrap material not suitable for recycling for flight-quality products.

\section{ELECTRODE FABRICATION}

During the year, fabrication of three electrodes from iridium powder was completed, and fabrication of a fourth electrode was begun. The E2 and E3 electrodes were fabricated from electron-beam-melted buttons produced from E-batch powder. The D2 electrode was fabricated from electron-beam-melted buttons produced from D-batch (41\%), B-batch (39\%), and C-batch (20\%) powders. No changes were made in the procedures for powder processing, electron-beam melting, or arc melting and alloying of buttons. The important technical change made in FY 1989 and implemented for all production this year is the elimination of water washing of the iridium powder. (Water washing remains optional in the powder-preparation procedure in the event that future lots of powder are no as clean.)

An additional electrode (CR4) was fabricated from recycle material in accordance with the established procedure. The recycle material consisted of cleaned, melted, extruded, or rolled iridium alloy from $\mathrm{C1}, \mathrm{D} 1, \mathrm{CR} 3$, and BF7 ingots manufactured during the years 1987 through 1989. Two pieces of the recycled iridium material, which appeared different in luster, were chemically analyzed and found to be within specification. Thus, CR4 is recycled material from powder lots $\mathrm{B}, \mathrm{C}$, and $\mathrm{D}$.

In addition, chemical analysis by isotopic dissolution was performed on a sample from the top center of the $\mathrm{E} 3$ ingot to evaluate the extent of thorium macrosegregation in recycle material used in electrode fabrication. The 72-ppm Th value for this sample indicates that macrosegregation is not significant. 


\section{CONSUMABLE-ELECTRODE MELTING}

Arc melting of four ingots was performed during the year using the MP-22 furnace. All of the melts were made using a 27 -mm-diam electrode in a 63 -mm-diam mold. Measurements of the spacing between the electrode and the mold flange were made with the electrode at the top, middle, and bottom of its allowed travel. Calculated clearances between the electrode and the mold were, in all cases, maintained above the specified 13-mm minimum (as compared to a clearance of $19 \mathrm{~mm}$ for a perfectly straight electrode and an ideally aligned system). The initial evacuated pressure levels were between 2 and $3 \mathrm{mPa}$; they generally rose during melting to between 20 and $40 \mathrm{mPa}$. The nominal current of the arc for all melts was $3000 \mathrm{~A}$, and the nominal voltage (dc electrode negative) after establishing the arc was 30 to $31 \mathrm{~V}$. At the end of each melt, the current was decreased to minimize the size of the internal cavity near the top of the melt.

The plots of current, voltage, and electrode position versus time are shown in Figs. 1 through 3 for E2, D2, and E3 electrodes, respectively. (Due to a computer error, no plot was obtained for the CR4 electrode.) The plots are very similar for all three melts. Each plot shows a startup lasting about $90 \mathrm{~s}$, a steady-state melting, and an ending hot-top melting. The voltage is allowed to rise to 34 or $35 \mathrm{~V}$ during the first $20 \mathrm{~s}$ of the melt in order to establish an estimated initial arc length of 25 to $50 \mathrm{~cm}$ to avoid sticking of the electrode to the molten pool. The potentiostat control of the electrode feed rate initially drives the electrode at a relatively high rate of $6 \mathrm{~mm} / \mathrm{s}$ for the first 60 to $80 \mathrm{~s}$. At this time, the arc length has shortened to decrease the voltage to between 29 and $30 \mathrm{~V}$ and is estimated to be less than $6 \mathrm{~mm}$. In each case, a number of short circuits indicated by sharp decreases in voltage are seen. These are indications of molten-metal drops from the electrode bridging to the pool for short periods of time. The electrode-feed controller decreases the feeding rate to about $3.5 \mathrm{~mm} / \mathrm{s}$ for about $10 \mathrm{~s}$. The lower f seding rate causes the arc length to increase. This completes the startup portion of the melt.

The stead-y-state portion of each melt is characterized by a current of 3000 to $3100 \mathrm{~A}$ and a voltage of 30 to $32 \mathrm{~V}$. The electrode-feed rate is relatively constant and is in the range of 3.9 to $4.2 \mathrm{~mm} / \mathrm{s}$ for the three plots shown. The final hot-top portion " the melt is begun when about $50 \mathrm{~mm}$ of electrode length remains, and the current is manually decreased. The hot-top portion is ended when the the electrode has melted back to the start of the iridium stub, and the power is shut off. The three plots (Figs. 1 through 3) show different hot-top parameters. At present, it is not known which parameters are most 


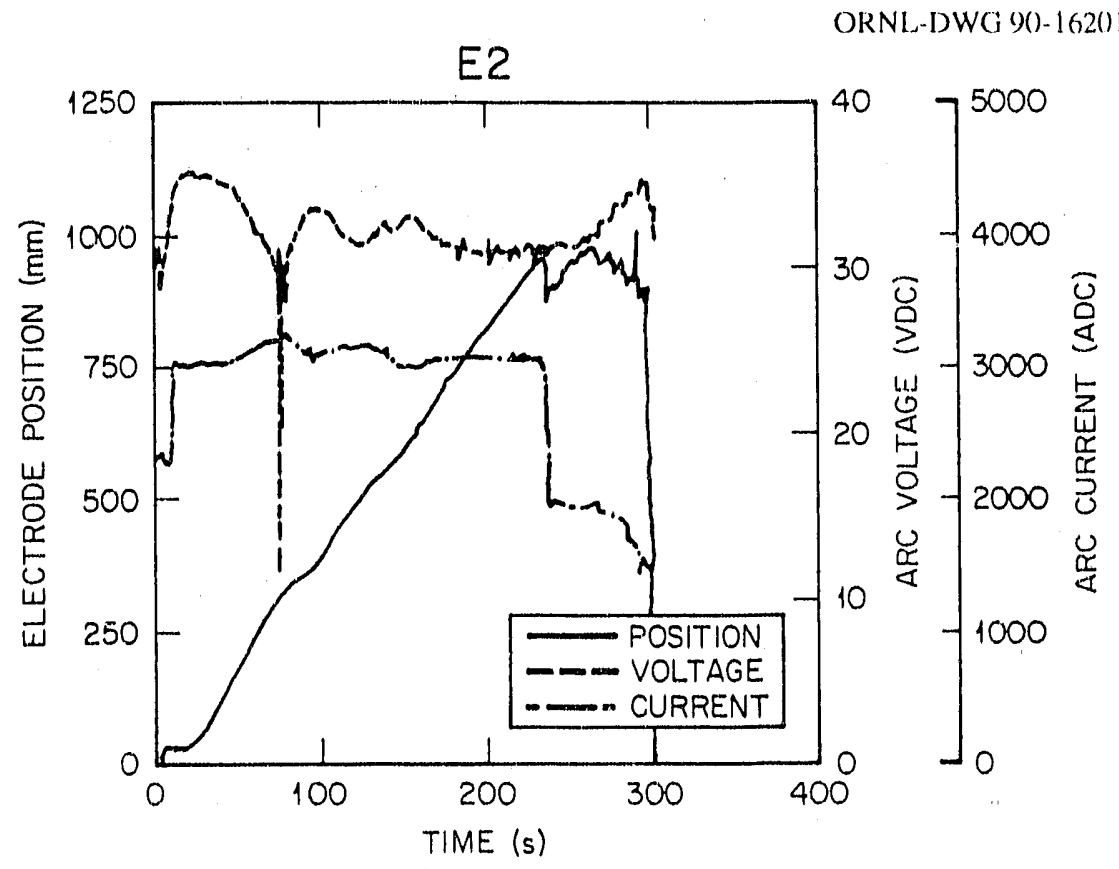

Fig. 1. Plot of arc-melting parameters for the E2 ingot shows maintenance of nominal potential of $30 \mathrm{~V}$ and nominal current of $3000 \mathrm{~A}$ after the initial 60-s melting.

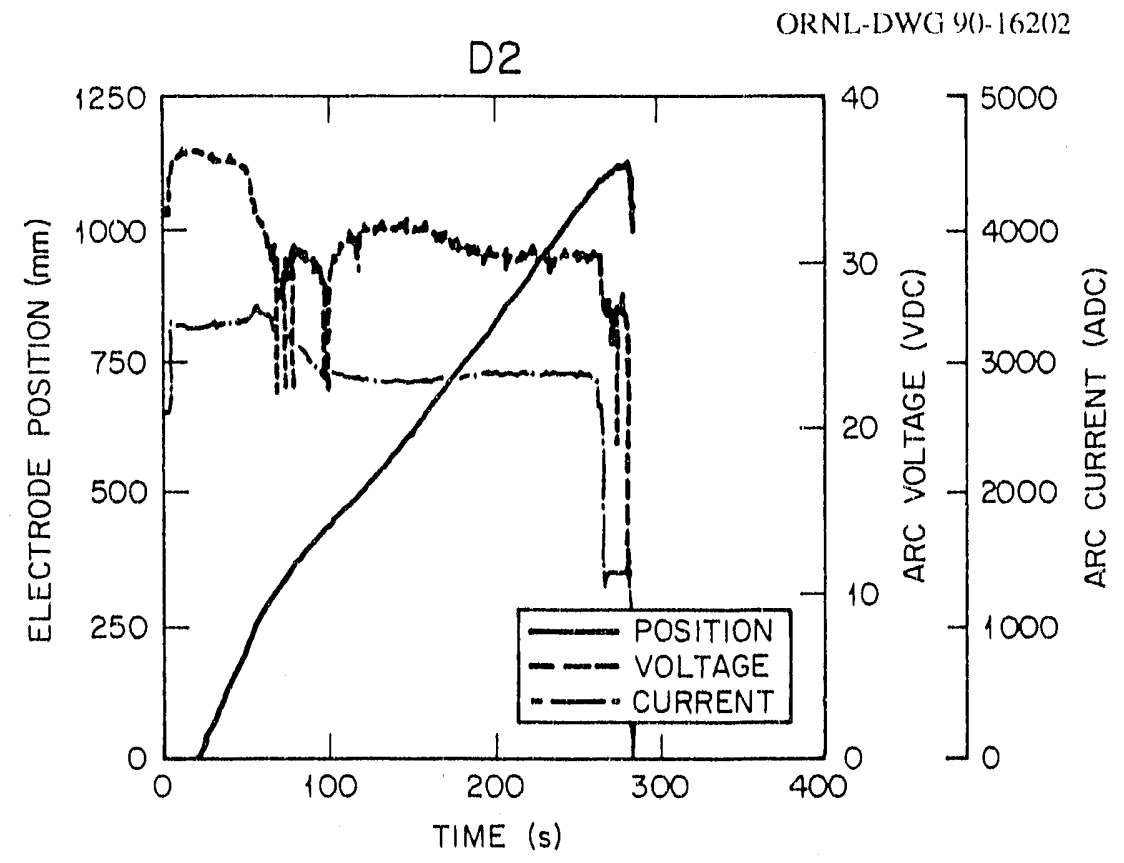

Fig. 2. Arc-melting parameters for the D2 ingot are similar to those seen in Fig. 1 for the E2 ingot. 


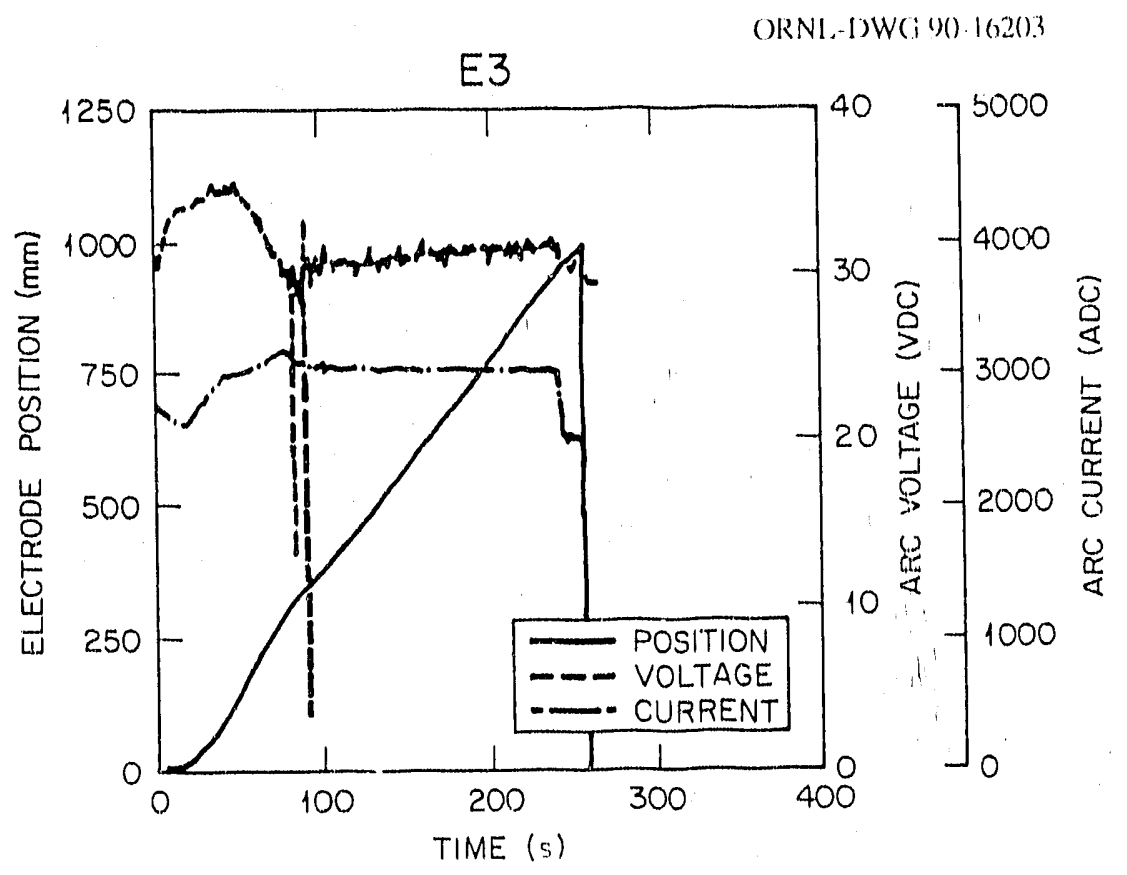

Fig. 3. Arc-melting parameters for the $\mathrm{E} 3$ ingot are similar to those seen in Fig. 1 for the E2 ingot.

effective in minimizing the depth of the internal pore, which must be cut from the top of each ingot for use as recycle material.

All four consumable-electrode, arc-melted ingots made during the year show similar appearance. All of the ingots are smooth over $90 \%$ or more of the surface. Some areas are rough due to unremelted splatter from the melting. The ingots were all cylindrically ground to remove a minimum of $0.5 \mathrm{~mm}$ from the surface, and the circular ends were cut and ground flat and perpendicular to axis. This removed all but a few regions of unremelted splatter.

\section{INGOT EXTRUSION}

The extrusions of the four arc-melted ingots described above were successfully performed using the same extruding parameters. The ground ingot is placed in a molybdenum can of $86.4-\mathrm{mm}$ diam and heated to $1425^{\circ} \mathrm{C}$ for $3 \mathrm{~h}$. The canned ingot is then extruded through a zirconia-coated, conical, steel die with a 19 - by 51 -mm-rectangular opening. The detailed extrusion parameters are listed in Table 1. The press capacity for this diameter of tooling $(8.2 \mathrm{MN})$ has, in the past, resulted in incomplete extrusions. 
Table 1. Current extrusion parameters for iridium alloys

\begin{tabular}{|c|c|}
\hline & Can \\
\hline \multirow[t]{2}{*}{$\begin{array}{l}\text { Material: } \\
\text { Outside diameter: } \\
\text { Inside diameter: } \\
\text { Base length: } \\
\text { Nose: } \\
\text { Tail plug: }\end{array}$} & $\begin{array}{l}\text { Molybdenum } \\
86.4 \pm 0.5 \mathrm{~mm} \\
\text { Clearance of } 0.25 \text { to } 0.10 \mathrm{~mm} \text { to ingot } \\
\text { Maximum } 1 \mathrm{~mm} \text { greater than ingot length } \\
45 \pm 3^{\circ} \text { cone with a flat diam of } 24 \pm 1 \mathrm{~mm} \\
\text { Approximately } 25-\mathrm{mm} \text { thick }\end{array}$ \\
\hline & Dle \\
\hline $\begin{array}{l}\text { Material: } \\
\text { Hardness: } \\
\text { Coating: } \\
\text { Outside diameter: } \\
\text { Length: } \\
\text { Die Oppening: } \\
\text { Entry flat: } \\
\text { Die exit angle: } \\
\text { Die exit length: } \\
\text { Die throat length: } \\
\text { Pinning hole diam: } \\
\text { Pinning hole separation: } \\
\text { Pinning hole depth: }\end{array}$ & $\begin{array}{l}\text { Extendo-die } \\
47 \text { to } 48 \mathrm{HRC} \\
0.5 \mathrm{~mm} \mathrm{ZrO}_{2} \text { over } 0.05 \mathrm{~mm} \text { nichrome } \\
90.22 \pm 0.05 \mathrm{~mm} \\
46.2 \pm 0.1 \mathrm{~mm} \\
19.05 \pm 0.1 \mathrm{~mm} \text { by } 50.8 \pm 0.1 \mathrm{~mm} \\
1.6 \pm 0.2 \mathrm{~mm} \\
3 \pm 1^{\circ} \\
6.4 \pm 0.2 \mathrm{~mm} \\
6.4 \pm 0.2 \mathrm{~mm} \\
95.25 \pm 0.03 \mathrm{~mm} \\
70.07 \pm 0.03 \mathrm{~mm} \\
15.9 \pm 0.2 \mathrm{~mm}\end{array}$ \\
\hline \multicolumn{2}{|r|}{ Liner } \\
\hline $\begin{array}{l}\text { Material: } \\
\text { Hardness: } \\
\text { Inside diameter: } \\
\text { Temperature: }\end{array}$ & $\begin{array}{l}\text { Extendo-dio } \\
47 \text { to } 48 \mathrm{HRC} \\
90.4 \pm 0.05 \mathrm{~mm} \\
470 \pm 25^{\circ} \mathrm{C}\end{array}$ \\
\hline \multicolumn{2}{|r|}{ Die backer } \\
\hline \multirow[t]{2}{*}{$\begin{array}{l}\text { Opening: } \\
\text { Pinning holes: }\end{array}$} & $\begin{array}{l}22.2 \pm 1.0 \mathrm{~mm} \text { by } 54.0 \pm 1.0 \mathrm{~mm} \\
\text { Same as for die }\end{array}$ \\
\hline & Blllet heating \\
\hline \multirow[t]{2}{*}{$\begin{array}{l}\text { Temperature: } \\
\text { Time: } \\
\text { Argon flow: }\end{array}$} & $\begin{array}{l}1425 \pm 25^{\circ} \mathrm{C} \\
3 \text { to } 6 \mathrm{~h} \\
20 \pm 5 \mathrm{cfh}\end{array}$ \\
\hline & Follower block \\
\hline $\begin{array}{l}\text { Material: } \\
\text { Diameter: } \\
\text { Length: } \\
\text { Prehcat temperature: } \\
\text { Preheat time: }\end{array}$ & $\begin{array}{l}\text { POCO graphite } \\
89 \pm 1 \mathrm{~mm} \\
76 \pm 3 \mathrm{~mm} \\
1300 \pm 25^{\circ} \mathrm{C} \\
15 \pm 5 \mathrm{~min}\end{array}$ \\
\hline \multicolumn{2}{|r|}{ Lubricants } \\
\hline Biilet: & $\begin{array}{l}67 \text { wt \% No. } 567 \text { glass }(-200 \text { mesh }) \\
33 \text { wt \% No. } 3 \mathrm{~KB} \text { glass } \\
\text { Manufacturer: Ceramic Solor and Chemical } \\
\text { Manufacturing Company, New Brighton, Pa. }\end{array}$ \\
\hline Liner: & $\begin{array}{l}\text { Necrolene (J. F. Hall and Company, Carnegie, Pa.) } \\
\text { Fiske } 201 \text { (G. Whitficld Richardson Co., } \\
\text { Philadelphia, Pa.) }\end{array}$ \\
\hline $\begin{array}{l}\text { Die: } \\
\text { Transfer time: } \\
\text { Nitrogen pressure: } \\
\text { Cooling medium: }\end{array}$ & $\begin{array}{l}\text { Same as liner } \\
25 \mathrm{~s} \mathrm{maximum} \\
\text { 15.5 MPa }(2350 \mathrm{psi}) \\
\text { Vermiculite }\end{array}$ \\
\hline
\end{tabular}


Since the implementation of improved ( xtruding parameters in FY 1989 (ref. 1), all extrusions have been successfully completed, although, in some cases, the maximum extruding load approached the press capacity.

The load-versus-time curves for all extrusions made with the improved parameters are shown in Fig. 4. The E2 and CR4 extrusions exhibit loads approaching the press capacity. The curve for CR 4 differs from the other curves in that there is no sharp, initial rise in the load, and the load increases continuously for most of the extrusion. A possible explanation is that the difference may be due to the molybdenum can, which was procured from a different vendor and is known to have a different thermomechanical history. Thus, the CR 1 can may be the cause of the initially lower flow stress, which would give initially lower load values that increase with work hardening of the molybdenum as the can temperature drops during the extrusion.

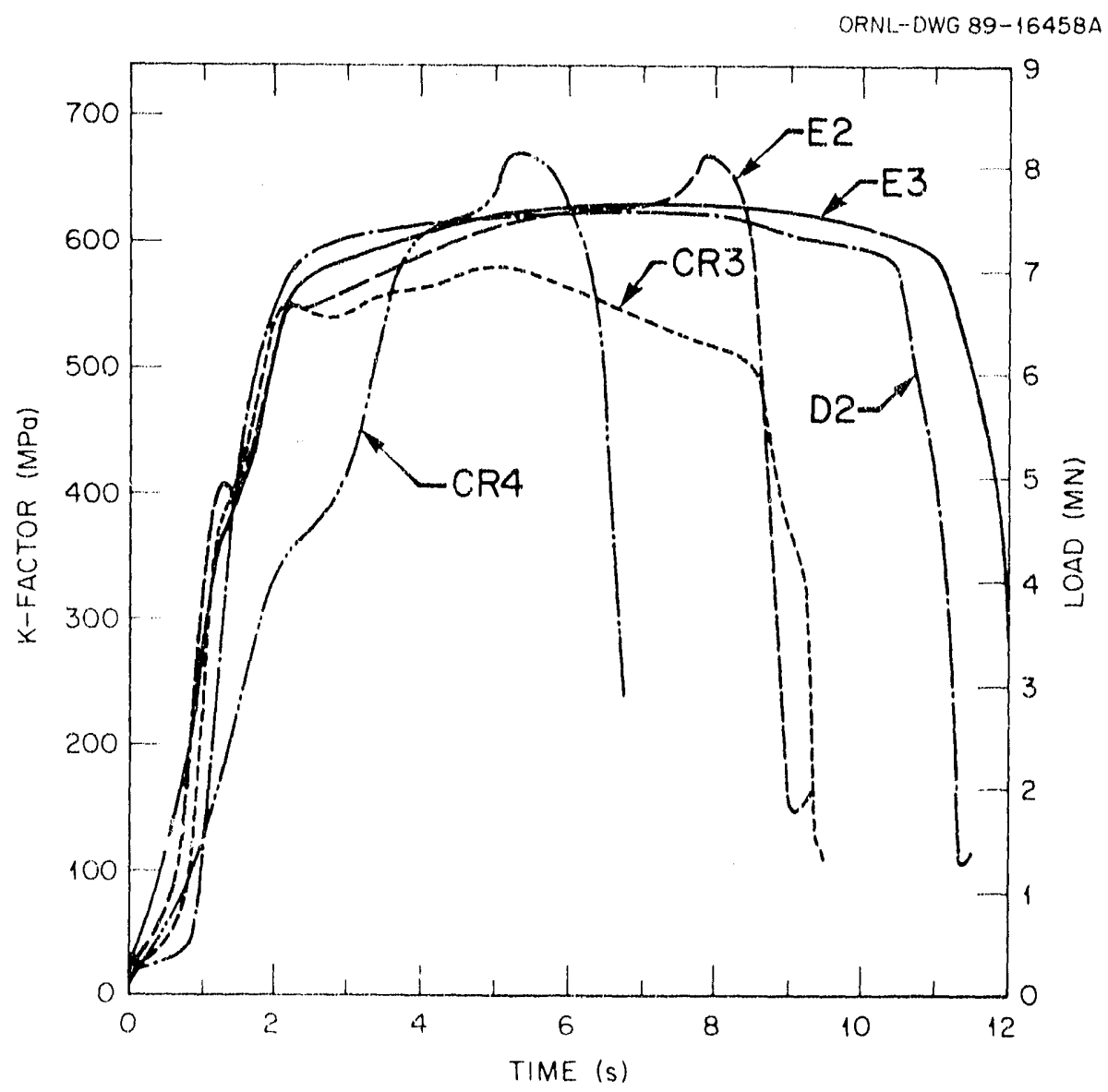

Fig. 4. Plots show that the CR4 extrusion exhibited significantly lower loads early in the extrusion than the D2, E2, and E3 extrusions but also a relatively high load similar to E2 that approached the press capacity of $8.2 \mathrm{MN}$. 


\section{SHEET ROLLING}

The extruded bars from E2, D2, and E3 ingots were rolled to produce sheet for machining into blanks. In addition, rolling was completed on eight sheets from the CR3 ingot. All rolling was performed using identical parameters. The only technical change made during the year was the addition of a single pass in the longitudinal direction for the first piece of bar from the nose of each extrusion. This change gave a more uniform thickness prior to the normal cross rolling and minimized subsequent variation in sheet width. During the final stages of roling withou: molybdenum covers, one of the 17 E2 sheets cracked along nearly its entire length. A total of 112 blanks were machined. Seventeen sheets from the D2 ingot were all successfully rolled and produced 118 blanks. The rolling of 5 of 16 sheets with molybdenum covers from the E3 ingot produced indentations or areas of insufficient thicknesses for production of blanks. Ten blanks were rejected for localized areas of insufficient thickness. The indentations are believed to be due to relative motion between the sheets and their associated covers. Similar behavior (described below) was observed previously on three sheets from the RS5 iridium-scrap ingot.

A study was conducted to identify methods of minimizing the risk of edge cracking or splitting along the rolling direction during the rolling of bare sheet using tungstencarbide rolls. The cause of the cracking is attributed primarily to the nonuniformity in the sheet thickness following rolling in the molybdenum covers. Measurements performed on the sheets from RS5 iridium-scrap ingot show thicknesses that are maximum at the center and decrease toward both the sides and the ends. After the initial cross rolling of the extrusion from 13 to $8 \mathrm{~mm}$, the variation in thickness is iypically $0.4 \mathrm{~mm}$. After further rolling to about $4.5 \mathrm{~mm}$, the variation in thickness is typically $0.2 \mathrm{~mm}$. Upon completion of the covered rolling, the variation in thickness is about $0.15 \mathrm{~mm}$. However, the variation was more on two sheets that slipped within the covers during rolling. In these cases, the iridium-sheet material moved under a portion sf the molybdenum cover that had not received as much reduction in thickness and, which in subsequent rolling, left an impression in the sheet.

Several special, tapered coveis were prepared and used for rolling at a preheat temperature of $1000^{\circ} \mathrm{C}$ from an initial thickness of about $2 \mathrm{~mm}$ to a final thickness of about $1 \mathrm{~mm}$ in 6 or 7 passes of $10 \%$ each. Three of the covers were prepared by masking a 25-mm-wide strip along the center of one side with tape and acid etching to remove 0.13 , 0.25 , and $0.38 \mathrm{~mm}$ of material, respectively, to produce a lengthwise step of the same 
height. Two of the three covers did produce a depression in the iridium-alloy sheet. For the cover with the $0.25-\mathrm{mm}$ step, the depression varied from $0.06 \mathrm{~mm}$ at the nose to nil at the tail. For the cover with $0.38-\mathrm{mm}$ step, the depression varied from $0.06 \mathrm{~mm}$ at the nose to $0.02 \mathrm{~mm}$ at the tail. The resultant $25-\mathrm{mm}$-wide depressions were not centered due to initial curvature of the sheets. Three additional covers with a tapered thickness, rather than a step change in thickness, were prepared. The tapers from the thicker center to thinner edge were $0.25,0.33$, and $0.36 \mathrm{~mm}$, respectively. It was hoped that this would produce a rolled iridium-alloy sheet with a more uniform thickness across the width. However, the movement of the sheets within the covers produced several regions up to $0.05-\mathrm{mm}$ thinner than anticipated. The initial curvature of the sheets also contributed to the problem of obtaining greater rolling reduction along the thicker central portion of the sheet.

Additional efforts to improve the use of the molybdenum covers are planned. One simple approach is the placement within the cover of molybdenum strips on both sides and of similar thickness to the iridium-alloy sheet. This is expected to minimize (1) variations in gage thickness across the width of the sheet, (2) warping of the sheet associated with nonuniform reduction in thickness of the molybdenum cover, and (3) tendency of the sheet to move within the cover during rolling.

A total of $0.2 \mathrm{~m}^{2}$ of foil was produced from the extruded bar of $\mathrm{BF} 7$ ingot. The yield of foil in FY 1990 is significantly reduced due to edge cracking. The foil is rolled in molybdenum covers to a thickness of 0.63 to $0.76 \mathrm{~mm}$ and recrystallized. The cracking, which begins after the recrystallized sheet is bare rolled to about $20 \%$ reduction, becomes less prevalent after about $50 \%$ reduction. The efforts described above to improve the uniformity of sheet thickness during covered rolling should also benefit the foil rolling operation.

\section{PRODUCT INSPECTION}

The inspections for acceptance of blanks per specification GPHS-M-185 consist of dimensional, nondestructive, chemical analysis, and metallographic testing. Three ingots (CR3, E2, and D2) were processed to produce 313 blanks for inspection during this fiscal year. Four blanks were rejected for dimensional nonconformances. These D2 blanks did not clean up during grinding. A total of eight other blanks with dimensional nonconformances were accepted through materials review board action (two CR3s, four E2s, and two D2 blanks). 
The nondestructive testing of blanks consists of ultrasonic, dye-penetrant, and visual inspections. Rejection of blanks for ultrasonic indications of defects has averaged 5\% during FY 1990. The yield of blanks through ultrasonic inspection is shown graphically in Fig. 5 for the last six years. The consistent high yields during FY 1990 above the goal of $85 \%$ are the result of the improved melting practice using the 63-mm-diam ingots combined with ingot surface conditioning and the improved extruding practice. The size and powder-batch source of each ingot are listed in Table 2.

The dye-penetrant and visual inspections of blanks produce few ultimate rejections because reworking by sanding, with subsequent reinspection, permits salvage at relatively low cost. Inspection of 85 blanks from the CR3 ingot resulted in dye-penetrant indications for 4 and visual indications for 12 . All but two were acceptable after a single reworking operation. Inspection of 112 blanks from the $\mathrm{E} 2$ ingot resulted in no dye-penetrant indications and visual indications for 13 , all of which were successfully reworked by sanding. A recent inspection of 116 blanks from the D2 ingot resulted in dye-penetrant indications in 3 and visual indications in 21. Reworking operations on these blanks are

ORNL-DWG 90-17399

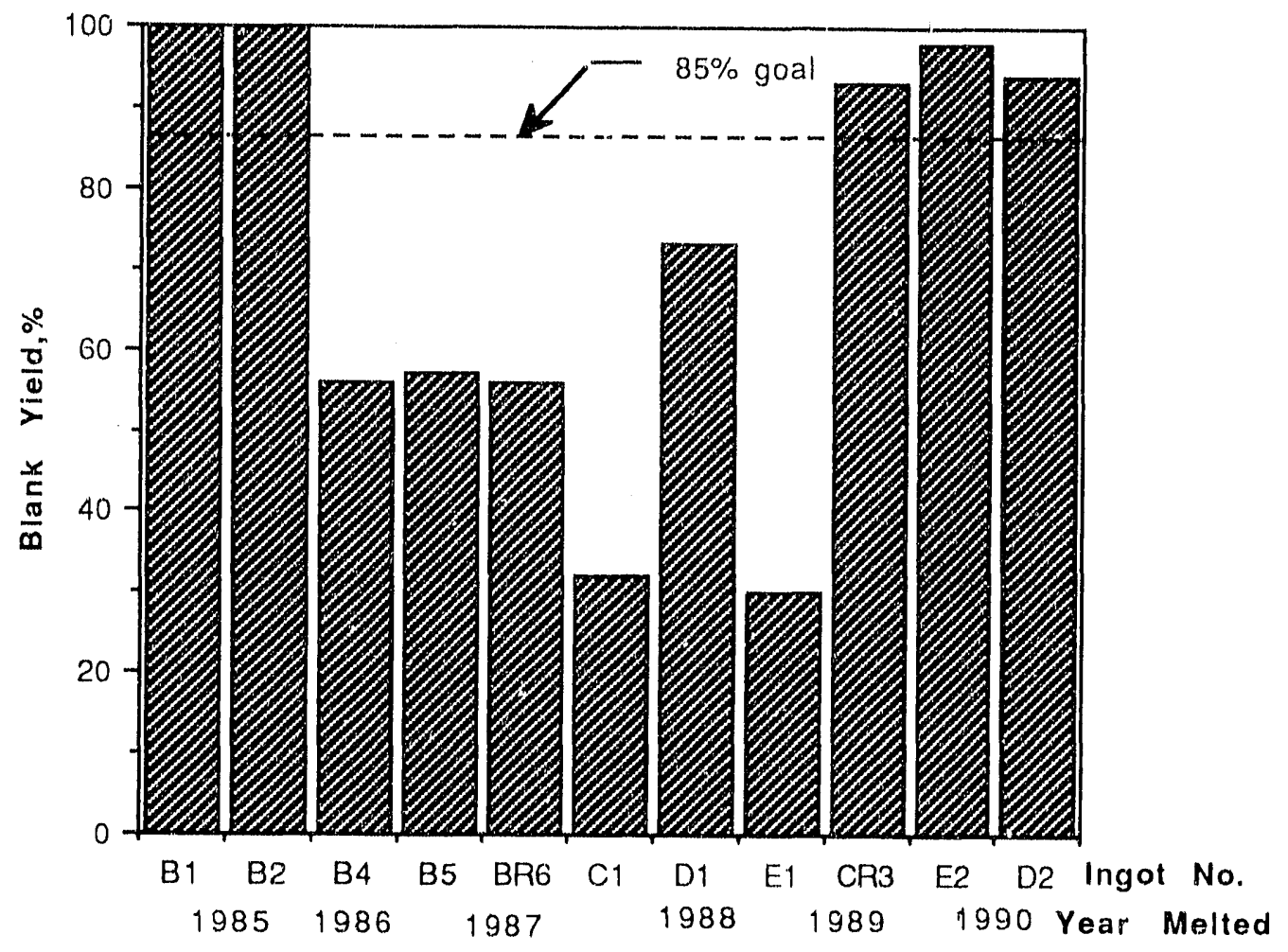

Fig. 5. Yields of blanks through ultrasonic examination have increased due to improved processing in FY 1990 and are above the task goal of $85 \%$. 
Table 2. Summary of ingot size and powder-batch source for consumable-electrode, arc-melted ingots

\begin{tabular}{|c|c|c|c|c|c|c|c|}
\hline \multirow{2}{*}{ Ingot } & \multirow{2}{*}{$\begin{array}{l}\text { Diameter } \\
(\mathrm{mm})\end{array}$} & \multirow{2}{*}{$\begin{array}{l}\text { Weight } \\
(\mathrm{kg})\end{array}$} & \multicolumn{5}{|c|}{ Powder batch source, \% } \\
\hline & & & B & $\mathrm{C}$ & $\mathrm{D}$ & $\mathrm{E}$ & $\mathrm{Z}$ \\
\hline B1 & 51 & 6.1 & 100 & 0 & 0 & 0 & 0 \\
\hline $\mathrm{B} 2$ & 51 & 6.4 & 100 & 0 & 0 & 0 & () \\
\hline $\bar{B} 4$ & 51 & 5.6 & 100 & 0 & 0 & () & 0 \\
\hline B5 & 51 & 5.5 & 100 & 0 & () & 0 & () \\
\hline $\mathrm{BR} G^{a}$ & 51 & 7.6 & 100 & 0 & 0 & 0 & 0 \\
\hline $\mathrm{C} 1$ & 51 & 7.7 & 0 & 100 & 0 & 0 & () \\
\hline D1 & 51 & 7.1 & () & 0 & 100 & () & 0 \\
\hline El & 63 & 8.5 & 0 & () & 0 & 100 & 0 \\
\hline $\mathrm{CR} 3^{b}$ & 63 & 8.9 & 47 & 25 & () & 0 & 28 \\
\hline $\mathrm{E} 2$ & 63 & 10.9 & 0 & 0 & () & 100 & 0 \\
\hline D2 & 63 & 11.0 & 39 & 20 & 41 & () & () \\
\hline
\end{tabular}

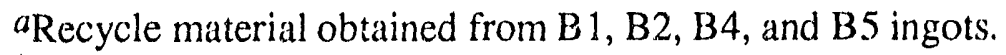
ingots.

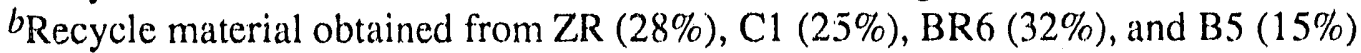

not completed. The larger number of visual indications (mostly for inclusions) for the D2 blanks is of concern, however, and is under investigation.

Metallographic inspections of iridium-alloy sheet include porosity, inclusions, degree of recrystallization, delaminations, and microhardness. No porosity or delaminations are observed on any of the sheets examined. All sheets show substantially less than the maximum limit of 5\% recrystallization in the fibrous condition. Only one of 47 sheet samples showed any visible inclusions. A single inclusion (about $4-\mu \mathrm{m}$ wide by $40-\mu \mathrm{m}$ long) was seen in one sheet from the E2 ingot and was identified as an alumina particle. All sheets show visible particles in the as-polished condition of an iridiumthorium intermetallic that are typically $1 \mu \mathrm{m}$ in height and 2 to $4 \mu \mathrm{m}$ in length. The incunsullic particles are larger and more prevalent than in sheet prepared from the $19-\mathrm{mm}$ rectangular, cross-section drop castings. Sheet prepared from 63-mm-diam ingots generally shows more and larger intermetallic particles than are seen in material from 51-mm-diam ingots. Representative, polished surfaces at a magnification of $200 \times$ are shown in Figs. 6 through 8 . The distribution of larger intermetallic particles in sheet produced from the larger ingots is also seen in the as-cast materials and may be associated 
PHOTO Y217.344

Fig. 6. Optical micrograph of as-polished specimen sheet MR424 produced from a 0.75 -mm-square drop casting shows only a few small intermetallic particles.

PHOTO Y217345

Fig. 7. Optical micrograph of as-polished sheet specimen B2-3 produced from a $51-\mathrm{mm}$-diam ingot shows more and larger intermet .llic particles than seen in sheet produced from drop castings. 
PHOTO Y217347

Fig. 8. Optical 1 erograph of as-polished sheet D2-12 specimen produced from a 63 -mm-diam ingot shows intermetallic particles, some of which have been elongated in the rolling direction.

with a decrease in the solidification rate with increased ingot size. The effect of intermetallic-particle distributions and morphology on material properties will be studied in FY 1991.

Microhardness measurements are made on the metallographic sample from each sheet using a Vickers indenter at a load equivalent to $1000 \mathrm{~g}$. The average of five hardness values is obtained from impressions made near the centerline of each sheet. All of the sheets examined show average hardness values within the specified range of 400 to $550 \mathrm{HV}$. The results are summarized in Table 3.

Table 3. Summary of Vickers microhardness of iridium-alloy sheet

\begin{tabular}{|c|c|c|c|c|c|}
\hline \multirow{2}{*}{ Ingot } & \multirow{2}{*}{$\begin{array}{l}\text { Number of } \\
\text { sheets }\end{array}$} & \multicolumn{4}{|c|}{ Microhardness of sheets, $1000-\mathrm{g}$ load } \\
\hline & & Mean & $\begin{array}{l}\text { Standard } \\
\text { deviation }\end{array}$ & Minimum & Maximum \\
\hline $\mathrm{CR} 3$ & 14 & 465 & 10 & 450 & 484 \\
\hline $\mathrm{E} 2$ & 16 & 446 & 11 & 430 & 463 \\
\hline D2 & 17 & 430 & 6 & 417 & 443 \\
\hline
\end{tabular}


Chemical analysis of iridium-alloy sheet includes thorium by isotopic dissolution; aluminum, tungsten, and impurities by spark source mass spectroscopy (SSMS); oxygen by vacuum fusion; and carbon by combustion. The thorium analyses of sheets from CR3, $\mathrm{E} 2$, and D2 ingots (Table 4) show the values to fall within the specified range of 30 to $90 \mathrm{ppm}$ by weight. The larger variability in sheets from the CR3 ingot may be associated with the use of recycled materials, but the variation in thorium content is not larger than that of blanks from some ingots made directly from the powder in previous years.

Table 4. Summary of thorium analyses of iridium-alloy sheet

\begin{tabular}{lccccc}
\hline & & \multicolumn{3}{c}{ Thorium content, ppm by weight } \\
\cline { 3 - 6 } Ingot & $\begin{array}{c}\text { Number of } \\
\text { sheets }\end{array}$ & Mean & $\begin{array}{c}\text { Standard } \\
\text { deviation }\end{array}$ & Minimum & Maximum \\
\hline CR3 & 14 & 67 & 6 & 51 & 77 \\
E2 & 16 & 63 & 1 & 61 & 64 \\
D2 & 17 & 69 & 1 & 68 & 71 \\
\hline
\end{tabular}

The analyses for tungsten, aluminum, and impurities by SSMS are performed on every second sheet from each ingot and are within the specified limits for all sheets from all ingots. The impurity levels analyzed $\leq 10 \mathrm{ppm}$ for all sheets from the CR3 ingot with the exception of iron, which was 20 to $30 \mathrm{ppm}$; molybdenum, which was $20 \mathrm{ppm}$ in one sheet (CR3-2); and sulfur, which was $30 \mathrm{ppm}$ in one sheet (CR3-7). The impurity levels analyzed $\leq 10 \mathrm{ppm}$ in all sheets from the E2 ingot with the exception of 30-ppm copper in the E2-7 sheet. The impurity levels analyzed $\leq 10 \mathrm{ppm}$ for all sheets from the D2 ingot without exception.

The carbon and oxygen analyses of the sheets were all within the specified limits of $35 \mathrm{ppm}$ maximum for carbon and $50 \mathrm{ppm}$ maximum for oxygen, with the exception of one analysis for D2-14 sheet, which is being repeated. The carbon analyses have historically shown a large scatter in values with occasional, nonrepeatable values above the specification limit. Additional work is planned to determine if this variability in carbon analyses from adjacent samples of a sheet is due to inhomogeneity in the sheet or associated with the analysis technique. 


\section{CONCLUSIONS}

The following conclusions are drawn from the experience in processing iridiumalloy-sheet products during FY 1990:

1. The use of the 63-mm-diam ingot in combination with an improved extruding process has dramatically decreased the rate of rejection of finished blanks for ultrasonic indications of defects.

2. The production process has met the program goal of a minimum $85 \%$ acceptance rate for finished blanks.

3. An intermetallic compound of iridium and thorium is present in the DOP-26 alloy and is seen as larger size particles in material produced from 63-mm-diam ingot than from 19-mm-square, cross-section drop castings. The particles are somewhat larger for material from 63-mm-diam ingots than for material from $51-\mathrm{mm}$-diam ingots.

4. Efforts to achieve a more uniform sheet thickness during rolling of iridium-alloy sheet within molybdenum covers, by use of a tapered cross section on the covers, were not successful. Other variations in the design of the covers should be evaluated as a means to increase product yields by minimizing sheet splitting and cracking during bare rolling.

\section{ACKNOWLEDGMENTS}

The author thanks W. J. Barnett (Department of Energy, Office of Special Applications), V. K. Sikka, and M. M. Martin for useful discussions of this work; K. V. Cook and R. A. Cunningham, Jr., for performing the nondestructive testing; C. E. Dunn, K. S. Blakely, C. R. Howell, J. D. Vought , E. C. Hatfield, and N. M. Atchley for performing the fabrication work; G. C. Marsh for performing the metallography; R. L. Heestand and E. P. George for manuscript review; and M. L. Atchley for preparing the manuscript.

\section{REFERENCES}

1. C. T. Liu, H. Inouye, and A. C. Schaffhauser, Metallurgical and Mechanical Properties of Thorium-Doped Ir-0.3\% W Alloys, ORNL-5616, Union Carbide Corp. Nuclear Div., Oak Ridge Natl. Lab., 1980. 
2. R. L. Heestand, G. L. Copeland, and M. M. Martin, A Consurnable Arc-Melting, Extruding, and Rolling Process for Iridium Alloy Sheet, ORNL-6720, Martin Marietta Energy Systems, Inc., Oak Ridge Natl. Lab., 1986.

3. E. K. Ohriner, Iridium Alloy Processing Experience in FY 1989, ORNL/TM-11565, Martin Marietta Energy Systems, Inc., Oak Ridge Natl. Lab., 1990. 


\section{INTERNAL DISTRIBUTION}

$\begin{aligned} \text { 1-2. } & \text { Central Research Library } \\ 3 . & \text { Document Reference Section } \\ 4-5 . & \text { Laboratory Records Department } \\ 6 . & \text { Laboratory Records, ORNL-RC } \\ 7 . & \text { ORNL Patent Section } \\ 8-10 . & \text { M\&C Records Office } \\ 11 . & \text { H. W. Berry } \\ 12 . & \text { K. V. Cook } \\ 13 . & \text { R. H. Cooper, Jr. } \\ 14 . & \text { E. P. George } \\ 15 . & \text { G. M. Goodwin } \\ 16 . & \text { K. J. Helle } \\ 17 . & \text { J. M. Holladay } \\ 18-22 . & \text { E. K. Ohriner }\end{aligned}$

$\begin{array}{ll}\text { 23. } & \text { M. M. Martin } \\ 24 . & \text { J. R. Mayotte } \\ 25 . & \text { V. K. Sikka } \\ \text { 26. } & \text { G. M. Slaughter } \\ \text { 27. } & \text { J. O. Stiegler } \\ 28 . & \text { G. B. Ulrich } \\ 29 . & \text { M. C. Vance } \\ 30 . & \text { A. D. Brailsford (Consultant) } \\ \text { 31. } & \text { Y. A. Chang (Consultant) } \\ 32 . & \text { H. W. Foglesong (Consultant) } \\ 33 . & \text { J. J. Hren (Consultant) } \\ 34 . & \text { M. L. Savitz (Consultant) } \\ \text { 35. } & \text { J. B. Wachtman, Jr. (Consultant) }\end{array}$

\section{EXTERNAL DISTRIBUTION}

36. AIR FORCE WEAPONS LABORATORY/AWYS, Kirtland Air Force Base, NMI 87117

M. J. Schuller

37. AMES LABORATORY, 242 Spedding Hall, Iowa State University, Ames, IA 50011

B. J. Beaudry

38. BATTELLE COLUMBUS LABORATORIES, 505 King Ave., Columbus, OH 4.3201

C. A. Alexander

39. DEPARTMENT OF METALLURGICAL ENGINEERING, Michigan Technological University, Houghton, MI 49931

C. L. White

40-41. FAIRCHILD INDUSTRIES, 20301 Century Blvd., Germantown, MD 20874

R. T. Carpenter

E. A. Skrabek

42-43. EG\&G MOUND APPLIED TECHNOLOGIES, INC., P.O. Box 3000, Miamisburg, OH 45342

W. R. Amos

T. L. Buxton 
44-47. GENERAL ELECTRIC COMPANY, Astro-Space Div .ion, P.O. Box 8555, Building B, Philadelphia, PA 19101

R. F. Hartman, 29B12-KB

R. J. Hemler, 29B12-KB

J. R. Peterson, 29B12-KB

R. M. Reinstrom, 29B12-KB

48. JET PROPULSION LABORATORY, California Institute of Technology, 4800) Oak Grove Drive, Pasadena, CA 91103

R. W. Campbell

49. JOHNS HOPKINS UNIVERSITY, Applied Physics Laboratory, Johns Hopkins Road, Laurel, MD 20707

J. C. Hagan

50. LOS ALAMOS NATIONAL LABORATORY, P.O. Box 1663, Los Alamos, NM 87545

R. W. Zocher

51. NUS CORPORATION, 910 Clopper Road, Gaithersburg, MD 20878

B. Bartram

52-53. ROCKWELL INTERNATIONAL, Rocketdyne Division, 6633 Canoga Avenue, Canoga Park, CA 913()3

L. J. Auge

E. Baumeister

54. TELEDYNE ENERGY SYSTEMS, $110 \mathrm{~W}$. Timonium Road, Timonium, MD 21093

W. M. Brittain

55. WESTINGHOUSE ELECTRIC CORPORATION, Advanced Energy Systems, P.O. Box 158, Madison, PA 15663-0158

M. O. Smith

56-57. WESTINGHOUSE HANFORD COMPANY, P.O. Box 1970, Richland, WA 99352

R. L. Knecht

M. J. Wiemers

58. WESTINGHOUSE SAVANNAH RIVER COMPANY, Savannah River Site, Bldg. 221-HBL, Aiken, SC 29808

E. A. Franco-Ferriera 
59-67. U. S. DEPARTMENT OF ENERGY, NE-53, GTN, Washington, D.C. 20585
W. J. Barnett
V. J. Cassella
R. G. Lange
B. A. Cook
E. F. Mastal
R. R. Furlong
A. S. Mehner.
W. D. Owings
R. C. Racznski

68. U.S. DEPARTMENT OF ENERGY, Albuquerque Operations Office, P.O. Box 5400, Albuquerque, NM 87115

R. L. Holton

69. U.S. DEPARTMENT OF ENERGY, Dayton Area Office, P.O. Box 66, Miamisburg, OH 4.5342

J. A. Morley

70. U.S. DEPARTMENT OF ENERGY, Richland Operations Office, P.O. Box 55(), Richland, WA 99535

O. A. Farabee

71. U.S. DEPARTMENT OF ENERGY, Savannah River Operations Office,

P.O. Box A, Aiken, SC 29802

W. C. Dennis

72-73. DOE FIELD OFFICE, OAK RIDGE, P. O. Box 2001, Oak Ridge, TN 37831-6269

Assistant Manager, Energy Research and Development

E. E. Hoffman

74-83. DOE, OFFICE OF SCIENTIFIC AND TECHNICAL INFORMATION,

Office of Information Services, P.O. Box 62, Oak Ridge, TN 37831

For distribution by microfiche as shown in DOE/OSTI.45()(),

Distribution Category UC-528 (Space and Defense Reactor Power Systems) 

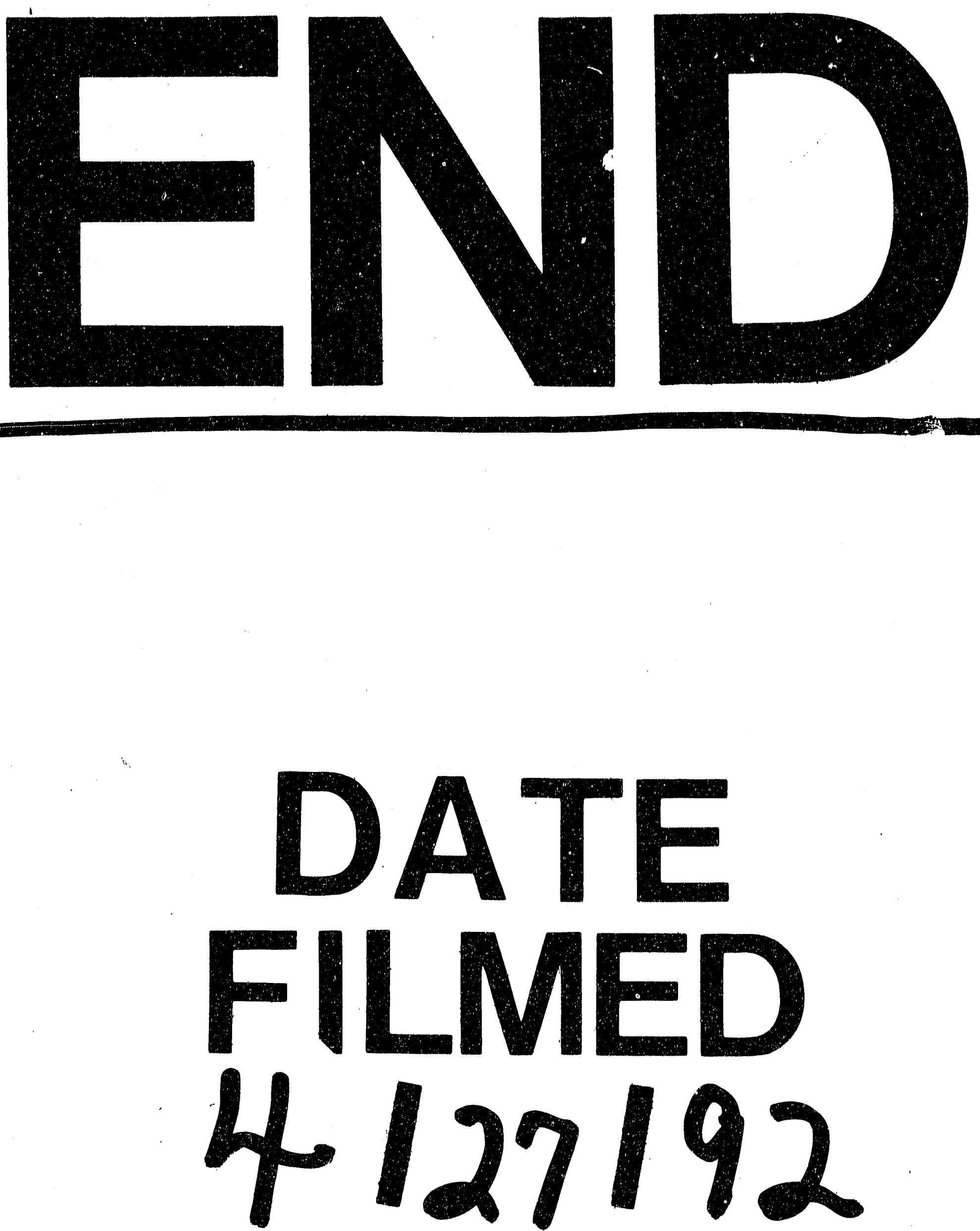